\title{
INTERNATIONAL CONGRESS OF OPHTHALMOLOGY
}

To the Editor of The British Journal of Ophthalmology.

Dear Sir,-In the November issue of The British Journal OF OPHTHALMOLOGY, there appeared an announcement of an International Congress of Ophthalmology, to be held in Washington, in 1922, which is not quite complete, and slightly in error in one respect.

I am authorized by the Committee in charge of the Congress to forward the following notice, with request that you publish it in an early number of the Journal. The notice to read as follows :

Under the auspices of the American Ophthalmological Society, the Ophthalmic Section of the American Medical Association, and the Academy of Ophthalmology and Oto-Laryngology, an International Congress of Ophthalmology will be held in Washington, April 18-22, 1922. The personnel of the temporary organization is as follows :

\begin{tabular}{|c|c|}
\hline President & Dr George F de Schweinitz \\
\hline Vice-President & Dr. Edward Jackson \\
\hline Secretary and Treasurer ... & Dr. Luther C. Peter \\
\hline $\begin{array}{c}\text { Chairman of Committee on Organiza- } \\
\text { tion }\end{array}$ & Dr. Edward C. Ellett \\
\hline Chairman of Committee on Scientific & \\
\hline Program & Dr. Edward Jackson \\
\hline Chairman of Committee on Finances & Dr. Lee M. Francis \\
\hline $\begin{array}{l}\text { Chairman of Committee on Arrange- } \\
\text { ments }\end{array}$ & Dr. William H. Wilmer \\
\hline $\begin{array}{c}\text { Chairman of Committee on Member- } \\
\text { ship and Credentials ... }\end{array}$ & Dr. Walter R. Parker \\
\hline
\end{tabular}

Application for membership may be made to the Chairman of the Membership and Credentials Committee, 1025 David Whitney Building, Detroit, Michigan, U.S.A. .The membership fee, which includes a copy of the Transactions, is $\$ 10.00$ in United States money.

If you will kindly insert the above notice in an early number of the Journal, it will be greatly appreciated by the temporary .officers of the proposed Congress.

Yours very truly,

Walter R. Parker,

Chairman, Membership and Credentials Committee.

December 22, 1920. 